\title{
The investigation of learned resourcefulness in terms of locus of control, sociotropy-autonomy personality traits, and demographic and professional variables in nurses
}

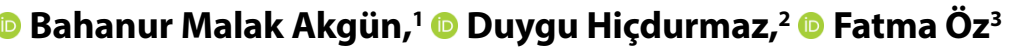 \\ 'Department of Nursing, Ardahan University School of Health Sciences, Ardahan, Turkey \\ ${ }^{2}$ Department of Psychiatric Nursing, Hacattepe University Faculty of Nursing, Ankara, Turkey \\ ${ }^{3}$ Department of Nursing, Lokman Hekim University Faculty of Health Sciences, Ankara, Turkey
}

\begin{abstract}
Objectives: In this study, we aimed to investigate learned resourcefulness in terms of locus of control, sociotropy-autonomy personality traits, and demographic and professional characteristics in nurses.

Methods: The participants of the study comprised 339 volunteering nurses working at Hacettepe Adult, Pediatric, and Oncology Hospitals. Study data were collected with Nurse Data Form, the Sociotropy-Autonomy Scale, the Locus of Control Scale, and Rosenbaum's Learned Resourcefulness Scale (RLRS).

Results: Nurses working at the institution for more than 25 years and working only the day shift had higher learned resourcefulness scores than their counterparts. There was a positive correlation between learned resourcefulness and autonomy. Among the sub-dimensions of locus of control, the only variable to have a significant relationship with learned resourcefulness was determined to be "self-control". Additionally, autonomous personality type, self-control, and belief in an unfair world were predictors of learned resourcefulness in nurses.

Conclusion: Nurses with low levels of learned resourcefulness are relatively younger and inexperienced. Thus, psychoeducation and group counseling might improve their autonomy, self-control, and cognitive coping strategies. Autonomous personality traits and self-control were the basic predictors of learned resourcefulness.
\end{abstract}

Keywords: Autonomy; learned resourcefulness; locus of control; nurse; sociotropy.

\section{What is known on this subject?}

- In the literature, no study has been found to determine whether sociotropy-autonomy personality traits and locus of control are predictors of the learned resourcefulness levels of nurses.

What is the contribution of this paper?

- In the study, nurses who worked at the institution for more than 25 years and who worked only the day shift had higher learned resourcefulness scores. Autonomous personality type, self-control, and belief in an unfair world were the predictors of learned resourcefulness in nurses.

What is its contribution to the practice?

- The nurses with low levels of learned resourcefulness are relatively younger and inexperienced. Therefore, psychoeducation and group counseling are needed to improve their autonomy, self-control, and cognitive coping strategies.
$\mathrm{N}$ ursing is a profession that involves stress due to its very nature of working with human life and serving those subjected to stress. ${ }^{[1-3]}$ Working in shifts, heavy workload, time pressure, limited authority in decision making, conflicts with supervisors and administrators, role ambiguity and conflicts, emotional stress due to patient problems, working with intensive care unit patients and dying patients, conflicts with patients and team members, problems related to the shifts, inadequate number of staff, negative effects of professional life on social life, inadequate rewarding, difficulties in approaching outraged and/or overly demanding patients, inadequate supplies, and insufficient support were all revealed to be among the factors leading to stress in nurses in related literature. ${ }^{[4-10]}$

Address for correspondence: Bahanur Malak Akgün, Ardahan Üniversitesi Sağlık Bilimleri Yüksekokulu, Hemşirelik Bölümü, Ardahan, Turkey Phone: +90 4782117575 E-mail: bahnur_mk@hotmail.com ORCID: 0000-0001-7151-0145

Submitted Date: November 21, 2017 Accepted Date: January 04, 2019 Available Online Date: August 05, 2019

${ }^{\circ}$ Copyright 2019 by Journal of Psychiatric Nursing - Available online at www.phdergi.org 
In a study conducted with a large group working directly with people, Maslach, Schaufeli and Leiter ${ }^{[11]}$ stated that skills in coping with work-related emotional stress had significant effects on individuals' professional identities and their professional behaviors. There exist some basic and effective behaviors and cognitive skills attained since birth in coping with stress-causing situations. Learned resourcefulness, as defined by Rosenbaum, ${ }^{[12]}$ is one of these cognitive skills. Learned resourcefulness is an acquired personality trait that helps the individuals regulate their inner reactions in a way to ensure appropriate behavioral modes, and it usually consists of a set of cognitive self-control skills and behaviors. It also involves certain behavioral traits such as skills to select and apply problem solving skills, self-talk skills to control cognitive processes, skills to postpone satisfaction, as well as an inclination to find yourself active and effective in response to events. ${ }^{[12]}$ Personal differences in learned resourcefulness play a significant role in determining the reactions the individuals display under stressful situations. ${ }^{[13]}$ According to Rosenbaum and Jaffe, ${ }^{[14]}$ the reactions displayed under the same stressful situation might vary because of differing levels of learned resourcefulness. Akgün and Ciarrochi ${ }^{[15]}$ established that individuals with high levels of learned resourcefulness can diminish the negative effects of stress by utilizing certain self-control skills.

As stated by Lazarus, ${ }^{[16]}$ the process of coping with stress involves a highly complicated and dynamic structure. Certain factors including individuals' personal features, ${ }^{[2]}$ their assessment of the situation, whether they attribute the cause of stress to internal or external factors, ${ }_{1}^{[17,18]}$ as well as the dimensions and features of the stress-inducing event are all significant factors in coping with stress effectively. Individuals who interpret events and results of specific behaviors based on internal factors like their own behaviors or relatively stable personal characteristics are thought to possess internal locus of control. However, those which are focused more on external factors such as luck, fate, and effects of other strong people or entities are thought to have external locus of control characteristics. ${ }^{[19-21]}$ People with an internal locus of control utilize problem-based coping strategies, which are more harmonious ways of coping, whereas those with an external locus of control use emotion-based coping strategies. ${ }^{[21]}$

The meaning individuals attach to a specific event and the way they perceive events are affected by their personality traits or characteristics. ${ }^{[2,9,22-27]}$ Therefore, our personality traits, the way we perceive an event, and our assessment of our own skills in coping with the event all effect whether we define an event as "manageable" or "unmanageable."[22,28,29]

Sociotropy-autonomy personality traits are another personality grouping type and display similarities with the grouping based on locus of control. Whereas autonomous personality traits are similar to an internal locus of control, sociotropic personality traits are similar to an external locus of control. Sociotropy indicates a dependency on others, but autonomy indicates more self-reliance. ${ }^{[30]}$ Akkaya $_{1}^{[31]}$ Aydın, ${ }^{[2]}$ Ceylan, ${ }^{[24]}$ and Beck et al. ${ }^{[30]}$ indicate that sociotropy and autonomy personality traits are determinants in coping with stress.

The stress-inducing nature of the nursing profession necessitates efficient dealing with stress. In order to improve coping skills of nurses, it is first necessary to determine the problem areas encountered and the group of nurses most at risk. Therefore, this study investigated learned resourcefulness and its relationships with locus of control, sociotropy-autonomy personality traits, and demographic and professional characteristics in nurses. In our literature search, we did not encounter any study questioning whether sociotropy-autonomy personality traits and locus of control of nurses are predictors of their learned resourcefulness. Therefore, this study is the first to determine the predictors of learned resourcefulness in nurses. In addition, we have revealed the relationship between the levels of learned resourcefulness of the nurses and their demographic and professional characteristics, locus of control, and sociotropy-autonomy. We sought answers to the following questions:

1. What is the relationship between low and high learned resourcefulness levels and sociotropy-autonomy personality traits?

2. What is the relationship between low and high learned resourcefulness levels and locus of control?

3. Which descriptive characteristics, sociotropy-autonomy personality traits, and locus of control sub-dimensions are the predictors of learned resourcefulness?

\section{Materials and Method}

We conducted a descriptive cross-sectional study designed to answer the research questions. A sampling method was not used. Nurses who volunteered to participate in the study created the sample. The study participants included 339 clinical nurses working at the Adult, Pediatric, and Oncology Hospitals of Hacettepe University. Of these, 189 worked at the adult hospital, 87 at the pediatric hospital, and 63 at the oncology hospital.

\section{Data Collection Tools}

Nurse Data Form: We designed this form to obtain data about the demographic and professional characteristics of nurses. The form included variables such as age, marital status, level of education, duration in profession, duration at the institution, service worked in, duty in the service, pattern of work, number of days on duty per month, number of patients cared for, reason for choosing the profession, what their decision would be if they had the chance to quit or choose again, and the problems they faced most frequently on the job.

Sociotropy-Autonomy Scale (SAS): This scale that was developed by Beck, Epstein, Horisson and Emery (1983) measures two personality traits, namely Sociotropy (social dependency) and Autonomy (satisfying independency). It was adapted to Turkish, and tested for its validity and reliability by Şahin, 
Ulusoy and Şahin. ${ }^{[32]}$ Test-retest reliability of the original scale ranged from 0.65 to 0.88 for sociotropy and from 0.66 to 0.75 for autonomy. Alpha reliability coefficients of the Turkish form of the scale were found to be 0.70 and 0.81 for sociotropy and autonomy, respectively. ${ }^{[33]}$ In this study, Cronbach's alpha reliability coefficients for sociotropy and autonomy were found to be 0.88 and 0.87 , respectively. SAS utilized a 5 -point Likert scale consisting of 60 items: 30 sociotropy and 30 autonomy sub-scale items. For each item, the participants were expected to answer items in which 0 represents "does not apply", 1 represents "applies a little", 2 represents "applies moderately", 3 represents "applies strongly", and 4 represents "applies very strongly". The lowest and the highest scores that can be obtained for each sub-dimension is between 0 and 120. Because SAS consists of two separate dimensions, the scale has two total scores. In evaluating the scale, increasing scores in the sociotropy dimension reveal high sociotropic personality traits, whereas increasing scores in the autonomy dimension reveal a high level of autonomy in participants. The dimensions of the scale are evaluated separately and therefore the scale does not have an overall total score. In the sociotropy dimension, there are 10 items for Concern About Disapproval, 13 items for Attachment/Concern About Separation, and 7 items for Pleasing Others. In the autonomy dimension, there are 12 items for Individualistic or Autonomous Achievement, 12 items for Mobility/Freedom from Control of Others, and 6 items for Preference for Solitude. ${ }^{[33]}$

Locus of Control Scale (LCS): Dağ ${ }^{[20]}$ developed this 5-point Likert-type scale, which is based on, but more comprehensive than, Rotter's Internal/External Locus of Control Scale (RIELCS). LCS consists of 47 items because of the item analysis based on comparisons of LCS item-total correlations and extreme groups. The Cronbach's alpha internal reliability coefficient was found to be 0.92 and the test-retest reliability coefficient was determined to be 0.88 . Items reflecting a belief for inner control located predominantly under the largest (first) factor (18 items, $12.62 \%$; $a=0.87$ ) named "self-control." Items reflecting a belief for external control were located under the other four factors displaying significant combination. The second factor of the scale is "belief in luck" (11 items, 8.56\%; $\alpha=0.79$ ), third is "pointlessness of struggling" (10 items, 7.7\%; $\alpha=0.76$ ), fourth is "predestinarianism" ( 3 items, $6.03 \%$; $a=0.74$ ), and fifth is "belief in an unfair world" (5 items, 5.2\%; $a=0.61$ ). ${ }^{[20]}$ In our study, the Cronbach's alpha reliability coefficient was found to be 0.89 for self-control, 0.59 for belief in luck, 0.82 for pointlessness of struggling, 0.69 for predestinarianism, and 0.64 for belief in an unfair world. Ratings were 'does not apply at all' (1), 'applies a little' (2), 'applies' (3), 'applies strongly' (4), and 'applies completely' (5). An increase in scores denoted a belief for external locus of control. ${ }^{[20]}$

Rosenbaum's Learned Resourcefulness Scale (RLRS): The scale, developed by Rosenbaum (1983), is a 5-point Likert-type self-report scale that measures the extent an individual utilizes cognitive coping strategies for coping with stress and stress reactions. Turkish validity and reliability of the scale was con- ducted by Dağ. ${ }^{[21]}$ The Cronbach's alpha reliability coefficient was 0.78 and test-retest reliability was $0.80 .{ }^{[21,33]}$ In our study, the Cronbach's alpha coefficient was found to be 0.85 . The scale consists of 36 items. The responses to the items are "Very undescriptive of me", "A little descriptive of me", "Mostly descriptive of me", "Descriptive of me" and "Very descriptive of me". Items 4, 6, 8, 9, 14, 16, 18, 19, 21, 29, and 35 are reversely scored and a total score between 36 and 180 is obtained. Higher scores represent higher levels of self-control skills, that is, a more frequent employment of the coping strategies represented in the scale. ${ }^{[21,33]}$

\section{Data Collection}

To conduct the study, written permission was obtained from the relevant institution and from Hacettepe University Non-Invasive Clinic Research Ethics Committee as well for the assessment of ethical appropriateness. During the study, the nurses were first informed of the purpose of the study, that it was on a volunteer basis, and that the results of the study would be used only for scientific purposes. Then, the data collection instruments were provided to the nurses.

\section{Statistical Analysis}

Statistical analysis of the data was conducted using SPSS 16 package software. During the analysis of RLRS scores according to demographic characteristics of the nurses, demographic characteristics were independent variables and learned resourcefulness was the dependent variable. In sociotropy-autonomy and locus of control score distribution according to learned resourcefulness, learned resourcefulness was the independent variable and sociotropy-autonomy and locus of control scores were dependent variables. The significance level was set as $p<0.05$ in statistical analyses. Because the assumptions of parametric tests were met, the $t$ test was utilized to compare the means of two independent variable groups and the one way-ANOVA test was performed for more than two independent variable groups while comparing nurses' demographics scores and scores in the scales. When there was a significant difference between groups, the Scheffe test was utilized to perform pair-wise comparisons of mean scores. Stepwise regression was performed to predict learned resourcefulness. Pearson correlation was utilized to compute the correlation coefficient of variables that did not fit the model.

\section{Results}

Importantly, 133 of the participants were aged between 20 and $29(39.2 \%)$ and 142 were aged between 30 and 39 (41.9\%). Most participants were university graduates $(290,85.5 \%)$, working at the same institution for 1-9 years $(207,61.1 \%)$, and had been in this profession for $1-9$ years $(183,54 \%)$. Most participants' positions were titled as clinic nurses $(271,79.9 \%)$, whereas 68 (20.1\%) were supervisors. Many participants (223, 
$65.8 \%)$ stated they chose the profession willingly, 152 (44.8\%) stated they would not choose this profession again, and 180 $(53.1 \%)$ stated they would leave the job now if their conditions allowed it.

\section{Learned Resourcefulness Scores According to Demographic Characteristics of the Nurses}

There was no significant difference between the RLRS scores with respect to nurses' ages $\left(F_{2-336}=2.77 ; p=0.06\right)$, marital status $(t=-1.43 ; p>0.05)$, level of education $(t=-0.91 ; p>0.05)$, and $p o-$ sition title ( $\mathrm{t}=0.07 ; \mathrm{p}>0.05)$ (Table 1$)$.

There was a significant mean difference between nurses' RLRS scores with respect to nurses' duration of work ( $t=-2.50$; $\mathrm{p}<0.05$ ) (Table 1). This difference arose from significantly higher RLRS scores of long-term nurses (25 yr and above) (mean=130.96, SD=14.28) than short-term nurses $(1-25 \mathrm{yr})$ (mean=122.55, SD=16.29) (Table 1).

There was a significant mean difference between nurses' scores of learned resourcefulness with respect to the duration of the work at the same institution $(t=-2.49 ; p<0.05)$ (Table 1). The analysis revealed that RLRS scores of long-term employees (25 yr and above) (mean=131.45, SD=13.81) was significantly higher than that of short-term employees (1-25 yr) (mean=122.60, SD=16.30) (Table 1).

There was a significant difference between RLRS scores with respect to nurses' patterns of work $(t=2.58 ; p<0.05)$. Pairwise comparisons computed using the independent-samples $t$ test indicated that learned resourcefulness levels of only daytime duty employees (mean $=125.82, \mathrm{SD}=15.84$ ) were higher than those of night and day shift employees (mean=121.23, $\mathrm{SD}=15.58$ ) (Table 1).

Table 1. Learned resourcefulness scores with respect to demographics of nurses

\begin{tabular}{|c|c|c|c|}
\hline Demographic features & $\mathbf{n}$ & RLRS (Mean $\pm S D)$ & Statistical analysis \\
\hline \multicolumn{4}{|l|}{ Age } \\
\hline $20-29$ & 133 & $121.25 \pm 15.68$ & $\mathrm{~F}=2.77$ \\
\hline $30-39$ & 142 & $123.23 \pm 16.55$ & $p=0.06$ \\
\hline 40 and above & 64 & $127.05 \pm 16.45$ & \\
\hline \multicolumn{4}{|l|}{ Marital status } \\
\hline \multicolumn{4}{|l|}{ Level of education } \\
\hline Low level (high school and associate degree) & 21 & $120.05 \pm 18.44$ & $t=-0.91$ \\
\hline High level (under-graduate and graduate degree) & 318 & $123.38 \pm 16.14$ & $p=0.36$ \\
\hline \multicolumn{4}{|l|}{ Duration of work as a nurse } \\
\hline $1-25 \mathrm{yr}$ & 314 & $122.55 \pm 16.29$ & $\mathrm{t}=-2.50$ \\
\hline $25 \mathrm{yr}$ and above & 22 & $131.45 \pm 13.81$ & $p=0.01$ \\
\hline \multicolumn{4}{|l|}{ Position title } \\
\hline Clinic nurse & 271 & $122.51 \pm 16.35$ & $t=0.007$ \\
\hline Supervisor nurse & 68 & $125.81 \pm 15.84$ & $p=0.14$ \\
\hline \multicolumn{4}{|l|}{ Pattern of work } \\
\hline Night-only & 4 & $123 \pm 20.41$ & $\mathrm{t}=2.58$ \\
\hline Day-only & 142 & $125.82 \pm 15.84$ & $p=0.01$ \\
\hline Night and day shift & 193 & $121.23 \pm 15.58$ & \\
\hline \multicolumn{4}{|l|}{ Units they work in } \\
\hline Polyclinic & 48 & $126.52 \pm 17.61$ & $F=2.90$ \\
\hline
\end{tabular}


A significant difference was found in nurses' RLRS scores with respect to the units in which the nurses work $\left(F_{3-335}=2.90\right.$; $\mathrm{p}<0.05)$. However, pairwise comparisons computed using the Scheffe test indicated this difference was not significant (Table 1).

\section{SAS and LCS Scores according to Scores of Learned Resourcefulness}

In this study, 108 points, which was the midpoint of the RLRS scale, was taken as the reference point to divide the nurses into two groups as high and low learned resourcefulness. Those with learned resourcefulness level lower than 108 points were categorized in the "low group" whereas the ones with the scores equal to or higher than 108 points were included in the "high group." According to the results, $17.1 \%$ of the participants $(n=58)$ had a low level of learned resourcefulness (mean=99.03, SD $=6.61$, range $=36-107)$ and $82.9 \%(n=281)$ had a high level of learned resourcefulness (mean $=128.16$,
$S=12.86$, range $=108-180$ ). Later, sociotropy-autonomy and LCS scores were compared according to these groups.

When the distribution of SAS scores with respect to low and high learned resourcefulness were examined, nurses with a high learned resourcefulness level had significantly higher levels of total autonomy, personal success, freedom, and a preference for solitude compared to nurses with low learned resourcefulness levels ( $t$ values, respectively: $t=-4.89, t=-5.38$, $\mathrm{t}=-4.15, \mathrm{t}=-3.52 ; \mathrm{p}<0.05)$. On the other hand, nurses with a high level of learned resourcefulness had significantly higher levels of total sociotropy, separation anxiety, and satisfying others compared to nurses with low learned resourcefulness levels ( $t$ values, respectively: $t=-2.27, t=-3.09, t=-2.15 ; p<0.05$ ). There was no significant difference between nurses' rejection anxiety scores with respect to learned resourcefulness levels $(t=-0.85 ; p>0.05)$ (Table 2).

As for the distribution of locus of control scores with respect to low and high learned resourcefulness, nurses with high level

Table 2. Comparison of SAS and LCS scores of nurses with high and low learned resourcefulness levels

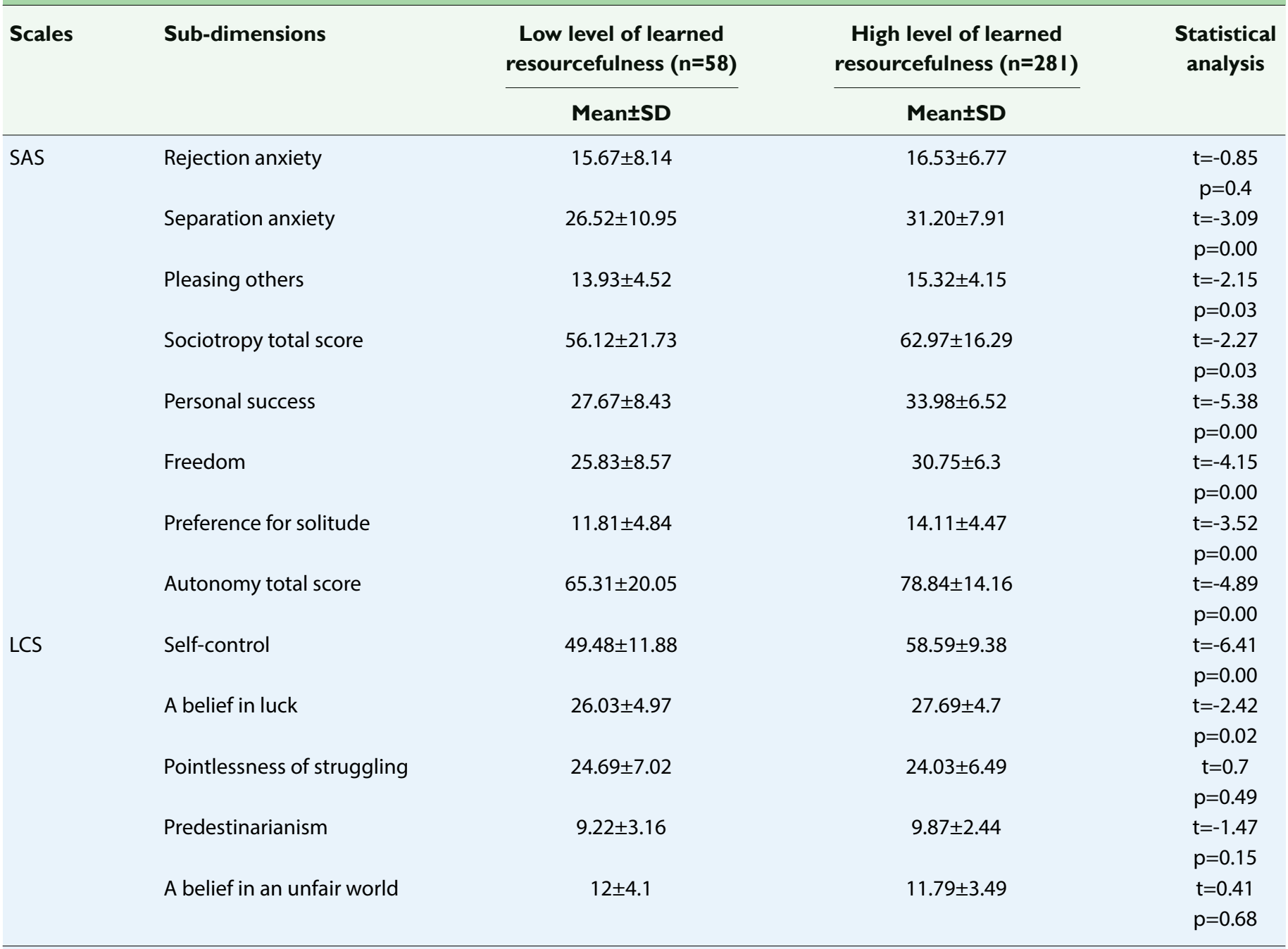


Table 3. Variables predicting learned resourcefulness score (staged hierarchical regression analysis results)

\begin{tabular}{|c|c|c|c|c|c|c|c|c|c|}
\hline Stages & Variables & $\mathbf{R}^{2}$ & $\mathbf{R}^{2}$ change & SS & $\mathbf{F}_{\text {value }}$ & B & $\begin{array}{l}\text { Standard } \\
\text { error }\end{array}$ & $\beta$ & $\mathbf{t}$ \\
\hline $1^{\text {st }}$ stage (demographic variables) & $\begin{array}{l}\text { Duration of work } \\
\text { as a nurse }\end{array}$ & 0.02 & 0.02 & 16.13 & 6.27 & 5.34 & 2.81 & 0.09 & 1.9 \\
\hline $2^{\text {nd }}$ stage (personality traits) & (SAS) autonomy & 0.16 & 0.14 & 13.77 & 33.49 & 0.24 & 0.05 & 0.24 & 4.74 \\
\hline $3^{\text {rd }}$ stage (locus of control) & (LCS) self-control & 0.28 & 0.12 & 14.11 & 45.69 & 0.59 & 0.08 & 0.38 & 7.51 \\
\hline
\end{tabular}

SAS: Sociotropy-autonomy scale; LCS: Locus of control scale.

Table 4. Pearson correlation coefficients of research variables

\begin{tabular}{|c|c|c|c|c|c|c|c|c|c|c|c|c|}
\hline & ( & (2) & (3) & (4) & (5) & (6) & (7) & (8) & (9) & $(10)$ & (II) & $(12)$ \\
\hline (1) RLRS & - & & & & & & & & & & & \\
\hline (2) Sociotropy & 0.05 & - & & & & & & & & & & \\
\hline (3) Autonomy & $0.4^{*}$ & $0.37^{*}$ & - & & & & & & & & & \\
\hline (4) Self-control & $0.5^{*}$ & $0.15^{*}$ & $0.44^{*}$ & - & & & & & & & & \\
\hline (5) Belief in luck & $0.12^{*}$ & $0.42^{*}$ & $0.35^{*}$ & $0.34^{*}$ & - & & & & & & & \\
\hline (6) Pointlessness of struggling & $-0.17^{*}$ & $0.34^{*}$ & $0.09^{*}$ & -0.03 & $0.47^{*}$ & - & & & & & & \\
\hline (7) Predestinarianism & 0.01 & $0.33^{*}$ & $0.12^{*}$ & 0.04 & $0.33^{*}$ & $0.32^{*}$ & - & & & & & \\
\hline (8) Belief in unfair world & $-0.17^{*}$ & $0.34^{*}$ & 0.09 & -0.03 & $0.47^{*}$ & $0.67^{*}$ & $0.32^{*}$ & - & & & & \\
\hline (9) Duration of work as a nurse & $0.14^{*}$ & -0.05 & 0.1 & 0.08 & $0.12^{*}$ & -0.02 & -0.07 & 0.02 & - & & & \\
\hline (10) Duration of work at the institution & $0.13^{*}$ & 0.02 & 0.1 & 0.1 & 0.1 & 0.04 & -0.09 & 0.04 & $0.93^{*}$ & - & & \\
\hline (11) Pattern of work & $-0.13^{*}$ & 0.06 & -0.07 & $-0.12^{*}$ & -0.04 & $0.16^{*}$ & 0.1 & $0.16^{*}$ & $-0.26^{*}$ & $-0.24^{*}$ & - & \\
\hline (12) Age & $0.13^{*}$ & -0.02 & 0.03 & $0.14^{*}$ & 0.05 & $-0.1^{*}$ & $-0.16^{*}$ & -0.1 & $0.43^{*}$ & $0.4^{*}$ & $-0.67^{*}$ & - \\
\hline
\end{tabular}

${ }^{*} \mathrm{p}<0.05$. RLRS: Rosenbaum's Learned Resourcefulness Scale.

of learned resourcefulness had significantly higher levels of self-control and belief in luck compared to the nurses with low learned resourcefulness levels (t values, respectively: $t=-6.41$, $\mathrm{t}=-2.42 ; \mathrm{p}<0.05)$. There was no significant difference between nurses' pointlessness of struggling, predestinarianism, and belief in an unfair world scores, which are external control subscales of the LCS, with respect to learned resourcefulness levels ( $\mathrm{t}$ values, respectively: $\mathrm{t}=0.7, \mathrm{t}=-1.47, \mathrm{t}=0.41 ; \mathrm{p}>0.05$ ) (Table 2 ).

\section{Variables Predicting Learned Resourcefulness}

In line with the purpose of the study, in the Stepwise Multiple Regression Analysis test, "age, duration of work as a nurse, duration of work at the institution, and pattern of work" were controlled variables in the first block. Personality variables (autonomy) in the second block and locus of control (self-control, a belief in luck, pointlessness of struggling, and a belief in an unfair world) in third block were predictor variables for learned resourcefulness. The results of the analysis are summarized in Table 3.

As can be seen in Table 3, in order to predict RLRS scores of nurses, "age, duration of work as a nurse, duration of work at the institution, and pattern of work" were entered as controlled variables in the first block. Duration of work as a nurse $\left(F_{1,337}=6.27 ; p<0.05\right)$ predicted learned resourcefulness significantly. It explained $2 \%$ of the variance in learned resourcefulness. In the second block, the "autonomous" personality trait $\left(F_{3,335}=33.49 ; p<0.05\right)$ significantly predicted learned resourcefulness. Autonomy explained $14 \%$ of the variance in learned resourcefulness. In the third block, "self-control" $\left(F_{2,336}=45.69\right.$; $p<0.05)$ and "belief of an unfair world" $\left(F_{4,334}=40.08 ; p<0.05\right)$ were significant predictors of learned resourcefulness. Selfcontrol explained $12 \%$ of the variance and belief of an unfair world explained $4 \%$ of the variance in learned resourcefulness. All significant variables explained $32 \%$ of the total variance.

Pearson correlation coefficients were computed to identify correlations between variables that did not fit the model (Table 4). Among the variables, "autonomy, self-control, believing in luck, duration of work as a nurse, duration of work at the institution, and age" had positive correlation with learned resourcefulness, whereas"pointlessness of struggling, belief in an unfair world, and pattern of work" had negative correlation. As can be seen in Table 4, the levels of significant correlations 
varied between 0.1 and 0.93 . Sociotropy and predestinarianism variables did not correlate with learned resourcefulness.

\section{Discussion}

In our study investigating the relationship between learned resourcefulness and locus of control, sociotropy-autonomy personality traits, and demographic and professional variables in nurses, we found those working as a nurse for a long time ( $>25 \mathrm{yr}$ ) and at the same institution for a long time had higher levels of learned resourcefulness than their counterparts did. According to correlation and regression analyses, duration of work as a nurse is related to learned resourcefulness and is a predictor variable of it. As is known, learning to be strong is related to effectively using coping strategies and self-control skills required for coping with stressful situations. ${ }^{[21,34]} \mathrm{An}$ increase in age naturally brings about an increase in the duration of work as a nurse, whether at the same institution or not. The maturity acquired through increasing age and the experience it brings might enable nurses to know themselves better and develop effective strategies for coping with stressful situations. Cimete, Gencalp, and Keskin ${ }^{[35]}$ also assert that the expectations and goals of the individual become more realistic as they mature. Similar to our findings, Yıldırım, Hacıhasanoğlu, and Karakurt ${ }^{[36]}$ state that nurses develop higher learned resourcefulness as their age and experience at work increase. Ernst et al. ${ }^{[37]}$ also found that senior nurses with more experience in the profession and institution experience less work-related stress and develop higher self-confidence over time. Similarly, Lambert, Lambert, and Ito ${ }^{[38]}$ suggest that the skills of nurses in establishing boundaries and in planned problem solving develop with age and increased vocational and institutional experience. According to Rosenbaum, ${ }^{[12]}$ learned resourcefulness accumulates over time through formal or informal learning processes, events, or experiences, and then the skills can be applied for coping with stress when confronted by adverse situations. However, nurses should not be expected to use cognitive coping strategies and self-control skills more effectively in stressful situations with learned skills acquired because of experience. Instead, psychoeducation programs can be organized that enable inexperienced nurses to develop cognitive coping strategies. One assumption of Lazarus and Folkman's $\mathrm{s}^{[28]}$ model is that cognitive reappraisal results in an increase in one's perceived ability to cope. Lazarus $^{[16]}$ said that the process of effective coping with stress involves a very complex and dynamic structure. In addition, inexperienced nurses can be given less stressful responsibilities.

A significant difference was not observed between the educational levels of the nurses. In addition, educational level did not have a significant predictor effect on learned resourcefulness in regression analyses. In another study, a meaningful difference was not observed between educational levels of nurses and their RLRS scores. ${ }^{[36]}$

We found that nurses working only the daytime shift had higher learned resourcefulness than the nurses working shifts (night and day shifts) did. There was a negative correlation between the pattern of work and learned resourcefulness. In Turkey, experience of 8-10 years is required for a nurse to work only the daytime shift. In the hospital in which the study was conducted, ten years of experience was required for daytime only shifts. The finding that these nurses had higher learned resourcefulness might be related to their seniority and professional and institutional experience. Therefore, this finding of the study is in alignment with the finding asserting that age brings about higher learned resourcefulness and those with more professional and institutional experience have higher levels of learned resourcefulness than those with less experience. Although Yıldırım, Hacıhasanoğlu, and Karakurt ${ }^{[36]}$ and Arıkan and Karabulut ${ }^{[39]}$ similarly found that nurses working multiple shifts had lower levels of learned resourcefulness than those working only the daytime shift, and the difference was not statistically significant. In another study, similar to our finding, the stress nurses experience was related to shift work. ${ }^{[40]}$ Night shifts have fewer team members and, thus, the nurses undertake more responsibilities regarding patient care. It is a time when the nurses have to resist their need for nighttime sleep, which is a requirement for a healthy body rhythm. When these factors, which require further attention and effort, are taken into consideration, an increase in the number of patients might hamper the careful thinking and decision-making skills, i.e. cognitive coping strategies, of the nurses regarding patient care. Similar to our findings, another study conducted in our country revealed that the nurses had less self-confidence and more work-related stress when they are obliged to spend less time with patients due to the high number of patients. ${ }^{[37]}$ Other studies conducted in other countries yield similar results. In numerous studies, the heavy workload of nurses is the major factor triggering stress. ${ }^{[41-45]}$

In our study, a significant difference was not found in learned resourcefulness scores of nurses with respect to the work unit. Similarly, another study found no significant difference based on the units the nurses worked in and their level of learned resourcefulness. ${ }^{[36]}$ The nurses working in pediatric clinics have the highest levels of stress. ${ }^{[4]]}$ In the studies conducted on this issue, the classification of units varies considerably, which inevitably limits comparing the relationship between learned resourcefulness and work units.

In our study, compared to those with low learned resourcefulness, the nurses with higher learned resourcefulness had higher levels of total autonomy, personal success, freedom, and preference for solitude. However, our study yielded another notable finding. The nurses with high learned resourcefulness had higher scores of total sociotropy, separation anxiety, and pleasing others, as well. The nurses with high learned resourcefulness seem to reveal both autonomous and sociotropic personality traits. However, further analysis revealed that the only variable with a positive relationship with learned resourcefulness in nurses that explained learned resourcefulness was autonomous personality trait. Among the sub-dimensions of locus of control, the only variable with a 
significant relationship with learned resourcefulness was selfcontrol in tests of significance and correlation and regression analyses. Furthermore, belief in an unfair world was a negative predictor of learned resourcefulness. Belief in luck had a positive relationship with learned resourcefulness. Pointlessness of struggling had a negative relationship with learned resourcefulness. The meaning the individuals attach to a specific event and the way they perceive events, on the other hand, are affected by their personality traits or characteristics. [2,9,22-27] Therefore, our personality traits, the way we perceive an event, and our assessment of our own skills in coping with the event all have an effect on whether we define an event as "manageable" or "unmanageable". [22,28,29]

Sociotropy-autonomy personality traits display similarities with the personality grouping based on locus of control. Whereas the autonomous personality trait shows similarity with an internal locus of control, the sociotropic personality trait shows similarity with an external locus of control. Sociotropy indicates a dependency on others, but autonomy indicates more self-reliance. ${ }^{[30]}$ Akkaya, ${ }^{[31]}$ Aydın, ${ }^{[2]}$ Ceylan ${ }^{[24]}$ and Beck et al..$^{[30]}$ have studies indicating that sociotropy and autonomy personality traits are determinants in coping with stress. Top ${ }^{[46]}$ found that personality traits effectively predict the level of learned resourcefulness of university students. In our literature search, we did not encounter any study questioning whether sociotropy-autonomy personality traits and locus of control of nurses are predictors of their learned resourcefulness. Therefore, this study is the first in the field to determine the relationship between learned resourcefulness in nurses and the above-mentioned variables.

In summary, these results demonstrate that the autonomous personality trait, self-control, and belief in an unfair world are among the explanatory factors of learned resourcefulness in nurses. Concentrating on these aspects in efforts to support nurses at risk will provide counseling activities that are more effective. White, Tata, and Burns ${ }^{[47]}$ define learned resourcefulness as an intra-individual way of coping. Among researchers from the field of education Ponton, Carr, and Confessore ${ }^{[48]}$ assert, parallel to our findings, that autonomous learning requires strength, personal initiative, and determination. Bekhet and Zauszniewski ${ }^{[49]}$ emphasize that the structure of self-control behavior encompasses learned resourcefulness. According to Zauszniewski, ${ }^{[50]}$ learned resourcefulness is acquired through interaction with others and manifests as the ability to manage daily activities independently. Weigl et al. ${ }^{[51]}$ states that control at work, positive relationships at work, and active coping behaviors trigger positive developments that have positive effects on people's work environment and their interpersonal relationships as well as enhance devotion to work. Although our study findings underlining the role of autonomy, self-control, and belief in an unfair world in developing learned resourcefulness are unsurprising, these findings significantly highlight the areas that need to be further strengthened for nurses to cope better with stressful situations.

\section{Limitations of the Study}

1. Our data encompasses only the nurses who were on duty at the time we carried out this research. The findings reflect the personality characteristics, learned resourcefulness, and locus of control of this group at a given time. Therefore, the data cannot be generalized without further investigation in different areas.

2. Because the scholarly literature on nurses' personality characteristics, learned resourcefulness, and locus of control is narrow and outdated, the Discussion section of this paper is limited to the present researchers' observations and experiences.

\section{Conclusion}

In our study, which aimed to investigate learned resourcefulness in terms of locus of control, sociotropy-autonomy personality traits, and demographic and professional variables in nurses, we reached our aims and have determined the related variables. The findings of the study will provide fruitful input to nurse supervisors and researchers in the field for determining the nurses at risk and helping with learned resourcefulness and coping.

According to the results of our study, nurses with short vocational experience, short experience at the institution, or working both the day and night shifts have lower levels of learned resourcefulness. Considering that the nurses in these groups might be at risk of developing detrimental coping strategies, psychoeducational or group counseling activities could be employed to help these nurses become more resourceful. In this respect, the focus group could be the relatively younger nurses with shorter professional and institutional experience. In our study, an autonomous personality trait, self-control, and belief in an unfair world were also determined to be predictors of learned resourcefulness. Concentrating on these two aspects in efforts to support the nurses at risk will provide counseling activities that are more effective.

Nurses working as nurses at the institution for more than 25 years and working only the day shift had higher learned resourcefulness scores. Other administrative arrangements might include increasing the number of nurses working the night shift and shortening the night work shift. Because these nurses are usually comprised of relatively younger nurses with less experience, teams of nurses working at night can be supported with more senior and experienced nurses.

In our study, other variables besides the autonomous personality trait and self-control were related to learned resourcefulness. Belief in luck was found to have a positive relationship whereas belief in an unfair world and pointlessness of struggling were found to have a negative relationship with learned resourcefulness. Autonomous personality type, self-control, and belief in an unfair world are the predictors of learned resourcefulness in nurses. It will be valuable to conduct a qualitative study with nurses to determine how these variables 
influence the nurses' perceptions of resourcefulness. Putting forward the views and opinions of the nurses through this kind of a qualitative study will guide us in determining the administrative regulations and counseling activities targeted at developing their learned resourcefulness.

Conflict of interest: There are no relevant conflicts of interest to disclose.

Peer-review: Externally peer-reviewed.

Authorship contributions: Concept - B.M.A., D.H.; Design B.M.A., D.H.; Supervision - B.M.A., D.H., F.Ö.; Fundings - B.M.A.; Materials - B.M.A., D.H.; Data collection \&/or processing - B.M.A.; Analysis and/or interpretation - B.M.A., D.H.; Literature search - B.M.A., D.H.; Writing - B.M.A., D.H.; Critical review - B.M.A., D.H., F.Ö.

\section{References}

1. Espeland KE. Overcoming burnout: how to revitalize your career. J Contin Educ Nurs 2006;37:178-84.

2. Aydın $\mathrm{H}$. The coping mecanism with stress and individual features of nursing working at psychiatry clinic. [Masters Thesis]. Istanbul: Haliç University; 2007.

3. Sinat Ö. A research on the burnout level of the nurses working at psychiatry clinics. [Masters Thesis]. Istanbul: Istanbul University; 2007.

4. Lee RT, Ashforth BE. A meta-analytic examination of the correlates of the three dimensions of job burnout. J Appl Psychol 1996;81:123-33.

5. Günüşen NP, Ustün B. Turkish nurses' perspectives on a programme to reduce burnout. Int Nurs Rev 2009;56:237-42.

6. Malak B, Üstün B. The Relation Between Nurses'Sociotropy-Autonomy Personality Features and their Burnout Levels. Journal of Hacettepe University Faculty of Nursing 2011;18:1-16.

7. International Labour Organization. Occupational Safety and Health. Available at: http://www.ilo.org/public/english/protection/safework/stress/whatis.html. Accessed Oct 16, 2017.

8. Payne N. Occupational stressors and coping as determinants of burnout in female hospice nurses. J Adv Nurs 2001;33:396405.

9. Shimizutani M, Odagiri Y, Ohya Y, Shimomitsu T, Kristensen TS, Maruta T, et al. Relationship of nurse burnout with personality characteristics and coping behaviors. Ind Health 2008;46:32635.

10. Patrick K, Lavery JF. Burnout in nursing. Aust J Adv Nurs 2007;24:43-8.

11. Maslach C, Schaufeli WB, Leiter MP. Job burnout. Annu Rev Psychol 2001;52:397-422.

12. Rosenbaum M. Learned resourcefulness, stress and self-regulation. In: Fisher S \& Reason J, editors. Handbook of Life Stress, Cognition and Health. Chichester: Wiley; 1988. p. 483-96.

13. Rosenbaum M, Ben-Ari K. Learned helplessness and learned resourcefulness: effects of noncontingent success and failure on individuals differing in self-control skills. J Pers Soc Psychol 1985;48:198-215.

14. Rosenbaum $M$, Jaffe $Y$. Learned helplessness: the role of individual differences in learned resourcefulness. Br J Soc Psychol
1983;22:215-25

15. Akgün $S$, Ciarrochi J. Learned resourcefulness moderates the relationship between academic stres and academic performance. Educational Psychology 2003;23:287-94.

16. Lazarus RS. Coping theory and research: past, present, and future. Psychosom Med 1993;55:234-47.

17. Folkman S. Personal control and stress and coping processes: a theoretical analysis. J Pers Soc Psychol 1984;46:839-52.

18. Uğurlu N, Ekinci M. The relationships between the locus of control of nurses, coping strategies of stress and display of mental symptom situtations. Ege Üniversitesi Hemşirelik Yüksekokulu Dergisi 2007;23:117-30.

19. Rotter JB. Generalized expectancies for internal versus external control of reinforcement. Psychol Monogr 1966;80:1-28.

20. Dağ İ. Kontrol odağı ölçeği (LCS): Ölçek geliştirme, güvenirlik ve geçerlik çalışması. Türk Psikoloji Dergisi 2002;17:77-90.

21. Dağ İ. Rosenbaum'un öğrenilmiş güçlülük ölçeğinin üniversite öğrencileri için güvenirliği ve geçerliği. Türk Psikiyatri Dergisi 1991;2:269-74.

22. Shaw C. A framework for the study of coping, illness behaviour and outcomes. J Adv Nurs 1999;29:1246-55.

23. Beutler LE, Moos RH, Lane G. Coping, treatment planning, and treatment outcome: discussion. J Clin Psychol 2003;59:115167.

24. Ceylan M. Stresle başa çıkmada bilişsel stratejilerin kullanılmasında cinsiyet ve kişilik değişkeninin etkisi. [Masters Thesis]. İzmir: Ege University; 2005.

25. Kangallı P. Sivas ili hastanelerinde çalışan hemşirelerin otonomi düzeyleri ve otonomiyi etkileyen mesleki ve kuramsal faktörlerin incelenmesi. [Masters Thesis]. Sivas: Cumhuriyet University; 2005.

26. Kaya N, Aştı T, Acaroğlu R, Kaya H, Şendir M. Determination of sociotropic /autonomic personality characteristics and related factors among nursing students. Cumhuriyet Üniversitesi Hemşirelik Yüksekokulu Dergisi 2006;10:1-11.

27. Çam O, Engin E. The effects of self awareness education on the individual performance standards of nurses who work in psychiatry clinic. Anatolian Journal of Psychiatry 2006;7:82-91.

28. Lazarus RS, Folkman S. Transactional theory and research on emotions and coping. European Journal of Personality 1987;1:141-69.

29. Baltaş A, Baltaş Z. Stres ve başa çıkma yolları. İstanbul: Remzi Kitapevi; 2012.

30. Beck R, Taylor C, Robbins M. Missing home: Sociotropy and autonomy and their relationship to psychological distress and homesickness in college freshmen. Anxiety, Stress, and Coping 2003;16:155-66.

31. Akkaya E. The relationship between the university students' autonomic-sociotropic personality characteristics and learned resourcefullness levels. [Masters Thesis]. Istanbul: Marmara University; 2009.

32. Sahin N, Ulusoy M, Sahin N. Exploring the sociotropy-autonomy dimensions in a sample of Turkish psychiatric inpatients. J Clin Psychol 1993;49:751-63.

33. Savaşır I, Şahin NH, Editör. Bilişsel-davranışçı terapilerde değer- 
lendirme: Sık kullanılan ölçekler. Ankara: Türk Psikologlar Derneği Yayınları; 1997.

34. Rosenbaum M. A schedule for assessing self-control behaviors: Preliminary findings. Behavior Therapy 1980;11:109-21.

35. Cimete G, Gencalp NS, Keskin G. Quality of life and job satisfaction of nurses. J Nurs Care Qual 2003;18:151-8.

36. Yıldırım A, Hacıhasanoğlu R, Karakurt P. Hemşirelerin stresle başa çıkmada bilişsel stratejileri kullanma düzeylerinin ve etkileyen faktörlerin belirlenmesi. Anadolu Hemşirelik Ve Sağlık Bilimleri Dergisi 2007;10:21-9.

37. Ernst ME, Messmer PR, Franco M, Gonzalez JL. Nurses' job satisfaction, stress, and recognition in a pediatric setting setting. Pediatr Nurs 2004;30:219-27.

38. Lambert VA, Lambert CE, Ito M. Workplace stressors, ways of coping and demographic characteristics as predictors of physical and mental health of Japanese hospital nurses. Int J Nurs Stud 2004;41:85-97.

39. Arıkan D, Karabulut N. Work-related strain in nurses and determination of the factors affecting this. Anadolu Hemşirelik Ve Sağlık Bilimleri Dergisi 2004;7:19-26.

40. Winwood PC, Winefield AH, Lushington K. Work-related fatigue and recovery: the contribution of age, domestic responsibilities and shiftwork. J Adv Nurs 2006;56:438-49.

41. Yau SY, Xiao XY, Lee LY, Tsang AY, Wong SL, Wong KF. Job stress among nurses in China. Appl Nurs Res 2012;25:60-4.

42. Healy CM, McKay MF. Nursing stress: the effects of coping strategies and job satisfaction in a sample of Australian nurses. J Adv Nurs 2000;31:681-8.

43. Pinikahana J, Happell B. Stress, burnout and job satisfaction in rural psychiatric nurses: a Victorian study. Aust J Rural Health 2004;12:120-5.

44. Chang EM, Daly J, Hancock KM, Bidewell JW, Johnson A, Lambert VA, et al. The relationships among workplace stressors, coping methods, demographic characteristics, and health in Australian nurses. J Prof Nurs 2006;22:30-8.

45. Wang W, Kong AW, Chair SY. Relationship between job stress level and coping strategies used by Hong Kong nurses working in an acute surgical unit. Appl Nurs Res 2011;24:238-43.

46. Top E. Evaluating the Personality Traits and Learned Resourcefulness Level of Students Studying in Different Faculties of University. International J. Soc. Sci. \& Education 2016;6:55-61.

47. White $R$, Tata P, Burns T. Mood, learned resourcefulness and perceptions of control in type 1 diabetes mellitus. J Psychosom Res 1996;40:205-12.

48. Ponton MK, Carr PB, Confessore GJ. Learning conation: A psychological perspective of personal initiative and resourcefulness. In: Loni HB \& Associates, editors. Practice \& theory in selfdirected learning. Schaumburg IL: Motorola University Press; 2005. p. 65-S2.

49. Bekhet AK, Zauszniewski JA, Wykle ML. Milieu change and relocation adjustment in elders. West J Nurs Res 2008;30:11329.

50. Zauszniewski JA. Operationalization of a nursing model for psychiatric nursing research. West J Nurs Res 1995;17:435-47.

51. Weigl M, Hornung S, Parker SK, Petru R, Glaser J, Angerer P. Work engagement accumulation of task, social, personal resources: A three-wave structural equation model. Journal of Vocational Behavior 2010;77:140-53. 